\title{
Output Voltage Ripple (OVR) Reduction of Boost Converter Using Particle Swarm Optimization
}

\author{
K. Prithivi1 ${ }^{*}$, M. Sathyapriya1, L. Ashok Kumar ${ }^{2}$ \\ ${ }^{1}$ Department of Electrical and Electronics Engineering, Kongu Engineering College, Erode, India \\ ${ }^{2}$ Department of Electrical and Electronics Engineering, PSG College of Technology, Coimbatore, India \\ Email:^k.prthv@gmail.com,priyaeee93@gmail.com, askipsg@gmail.com
}

How to cite this paper: Prithivi, K., Sathyapriya, M. and Kumar L.A. (2016) Output Voltage Ripple (OVR) Reduction of Boost Converter Using Particle Swarm Optimization. Circuits and Systems, 7, 40094023.

http://dx.doi.org/10.4236/cs.2016.712332

Received: May 10, 2016

Accepted: May 21, 2016

Published: October 28, 2016

Copyright $\odot 2016$ by authors and Scientific Research Publishing Inc. This work is licensed under the Creative Commons Attribution International License (CC BY 4.0).

http://creativecommons.org/licenses/by/4.0/

\begin{abstract}
KY Boost Converter, a modern invention in the field of non-isolated DC-DC boost converter is identified for minimum voltage ripple. KY boost converter is the combination of KY converter and traditional boost converter. Such a converter has continuous input and output inductor current, different from the traditional boost converter. And hence this converter is very suitable for very low-ripple applications. The Particle Swarm Optimization (PSO) based controller, FUZZY based controller and open loop KY boost converter are designed in MATLAB/Simulink model. The simulated results show a reduction in output ripple from $1.18 \mathrm{~V}$ of the existing open loop $\mathrm{KY}$ boost converter output to $0.54 \mathrm{~V}$ in the FUZZY logic controlled converter output. Further reduction in output ripple to $0.29 \mathrm{~V}$ is achieved in the proposed PSO based converter. The simulated results also show the variation of switching pulses based on the different existing and proposed method.
\end{abstract}

\section{Keywords}

Boost Converter, Particle Swarm Optimization (PSO), Output Voltage Ripple (OVR) Reduction

\section{Introduction}

For the function of the power supply using the low voltage battery, analog circuits, such as radio-frequency (RF) amplifier, audio amplifier, often need very high voltage to obtain enough output power and voltage amplitude. This is done by boosting the minimum voltage to the required high voltage. For such applications, the output voltage ripple must be taken into account purposefully. Regarding the conventional non-isolated voltage-boosting converter, their output currents are pulsating; thereby the corresponding output voltage ripple tends to be large. As generally approved, to overcome 
this problem, one way is the usage and low equivalent series resistance (ESR), another way is to add inductance-capacitance (LC) filter. In [1], the interleaved control scheme is employed in the dual buck-boost converters. In the literature [2] [3] [4], the voltagelift technique is utilized to boost the output voltage. Also several controlling techniques like coupling inductors [5], sliding mode converter [6] and loop bandwidth control [7] were used for voltage ripple reduction. But these converters [2]-[7] have one right-half plane zero in CCM mode. So it is not easy to achieve required boosted output voltage. And hence the KY boost converter [8] [9] [10] is presented to overcome this problem. But these converters [8] [9] [10] do not obtain the expected output voltage and also having large amount of output voltage ripple. The FUZZY logic controller based converter [11] is presented to overcome this problem. The FUZZY based converter [11] can produce the expected output voltage but the ripple reduction performance is not so good. To reduce the ripple in a very effective manner PSO based controller is used and the detailed illustration of the proposed converter is described herein, along with some experimental results to justify the effectiveness of such a converter.

\section{System Overview}

Figure 1 shows the overall block diagram of the controlled converter. Reduction of the output voltage ripple can be achieved by giving the proper switching pulse for the converter switch. The proper switching pulse is given by the proper controller design for PWM generator. Here the actual voltage $\left(V_{\text {act }}\right)$ and reference voltage $\left(V_{\text {ref }}\right)$ are taken as a feedback parameters for controller design. The output of the controller is a control signal which is compared with the reference signal in the PWM generator for producing the proper switching pulse to operate the KY boost converter. Based on the controller design the switching pulse get vary and based on the switching pulse variation the output voltage ripple reduces and output voltage increases. Here the supply for KY converter is given by battery source.

\section{KY Boost Converter}

Figure 2 shows the proposed positive-voltage KY boost converter composed of the KY converter combined with the traditional boost converter. The KY converter consist of

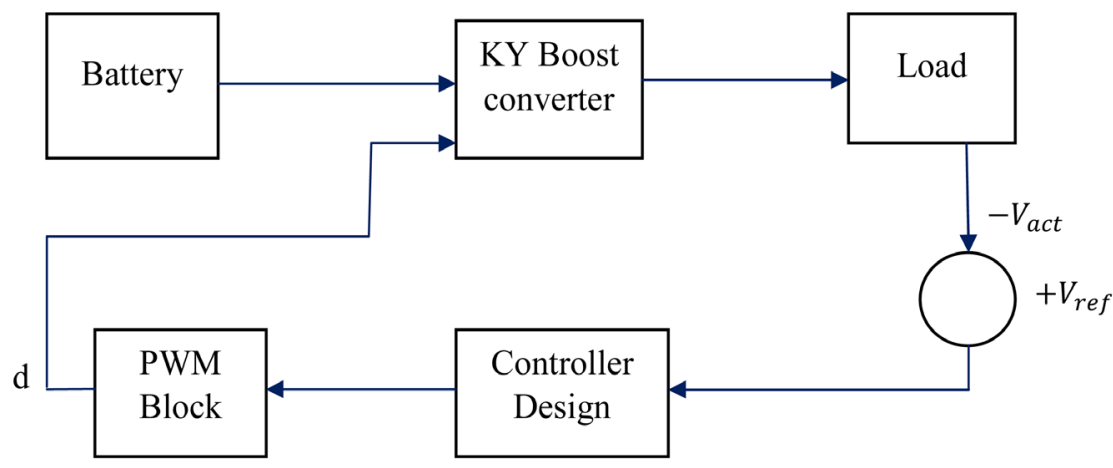

Figure 1. Block diagram of overall system. 


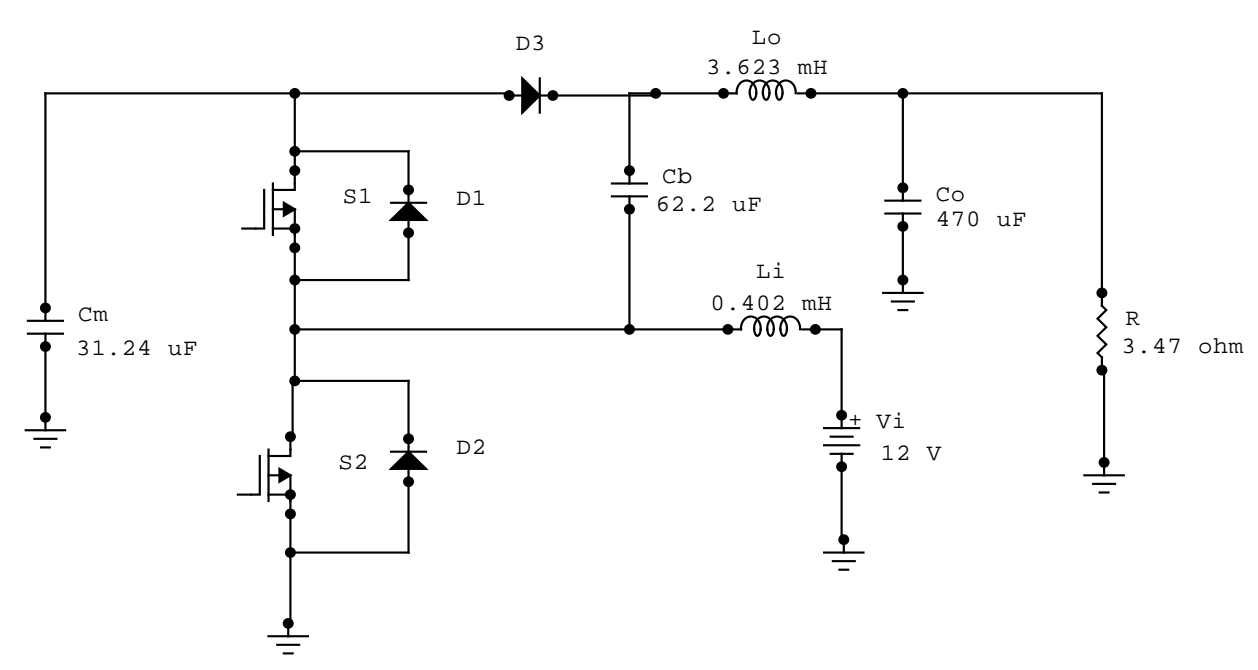

Figure 2. KY boost converter.

the switches $S_{1}$ and $S_{2}$, the diode $D_{b}$, the energy-transferring capacitor $C_{b}$, the output inductor $L_{0}$ and the output capacitor $C_{0}$. The input of the KY converter is retrieved by the buffer capacitor $C_{m}$. On the other hand, the traditional boost converter consists of the switches $S_{1}$ and $S_{2}$, the input inductor $L_{i}$. The output of the conventional boost converter is replaced by the buffer capacitor $C_{m}$. The buffer capacitor $C_{m}$ is a buffer between the KY converter and the traditional boost converter. The output load is represented by the load resistor $R$.

\subsection{Mode 1 Operation of KY Boost Converter}

In Figure 3, $S_{1}$ is turned off and $S_{2}$ is turned on. In this case, the negative terminal of $C_{b}$ is pulled to the ground and hence $D_{b}$ is forward biased and turned on. During this mode, $C_{m}$ is discharged whereas $C_{b}$ is charged. Therefore, the voltage across $L_{i}$ is $V_{i}$, thereby causing $L_{i}$ to be magnetized, whereas the voltage across $L_{0}$ is $V_{0}$ subtracted from $V_{C_{m}}$, thereby causing $L_{0}$ to be demagnetized. Also, the current flowing through $C_{0}$ is equal to $i_{L o}$ minus the current flowing through $R$. And hence, the corresponding differential equations are given by (1) to (4).

$$
\begin{gathered}
L_{i} \frac{\partial i_{L_{i}}}{\partial t}=V_{L_{i}} \\
L_{0} \frac{\partial i_{0}}{\partial t}=V_{C_{m}}-V_{0} \\
C_{m} \frac{\partial V_{C m}}{\partial t}=-i_{C b}-i_{L o} \\
C_{o} \frac{\partial V_{o}}{\partial t}=i_{L o}-\frac{V_{o}}{R_{L}}
\end{gathered}
$$

\subsection{Mode 2 Operation of KY Boost Converter}

In Figure $4, S_{1}$ is turned on and $S_{2}$ is turned off. In this case, $S_{1}$ is in the on-state 


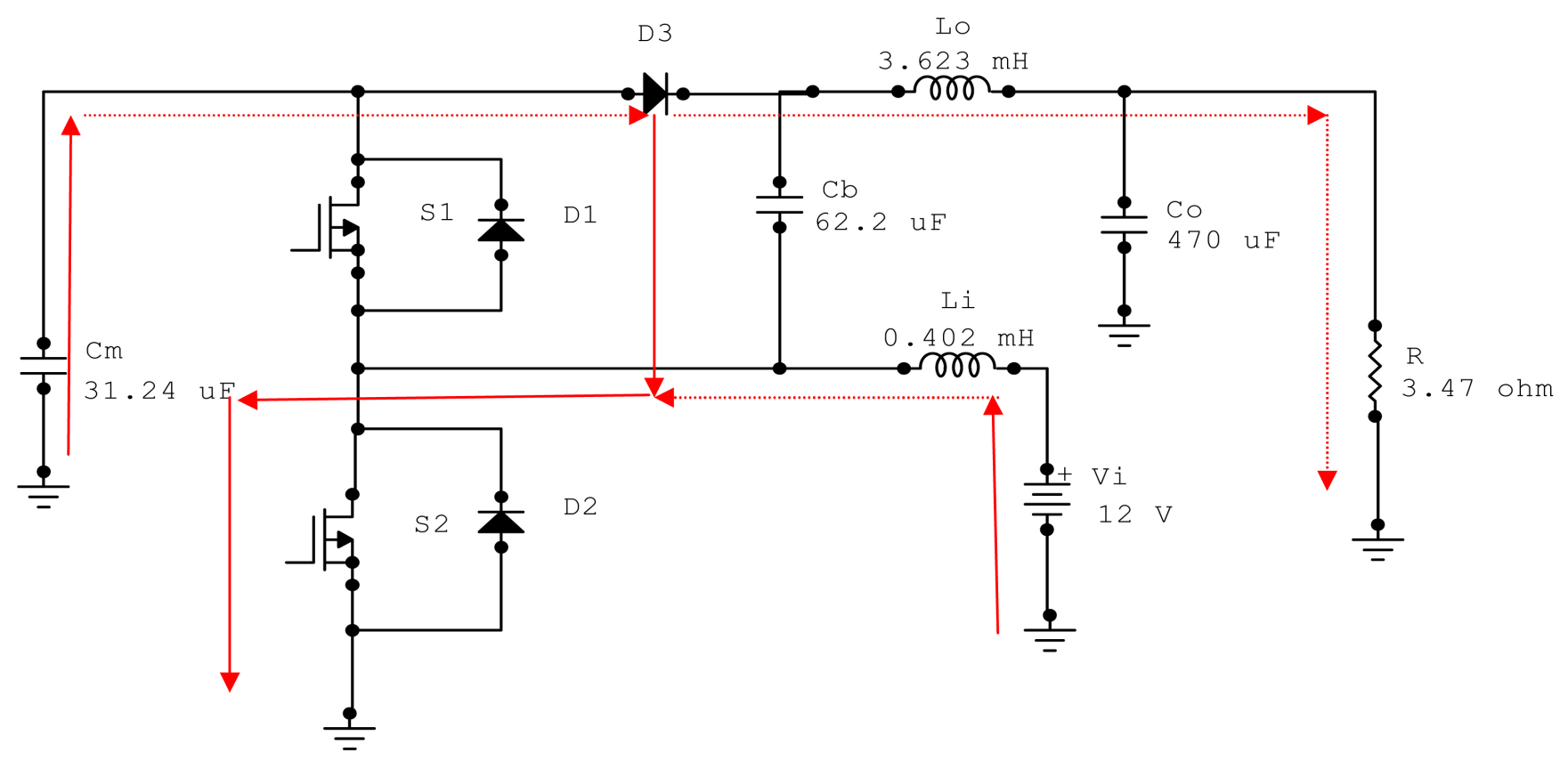

Figure 3. Power flow of mode 1 operation.

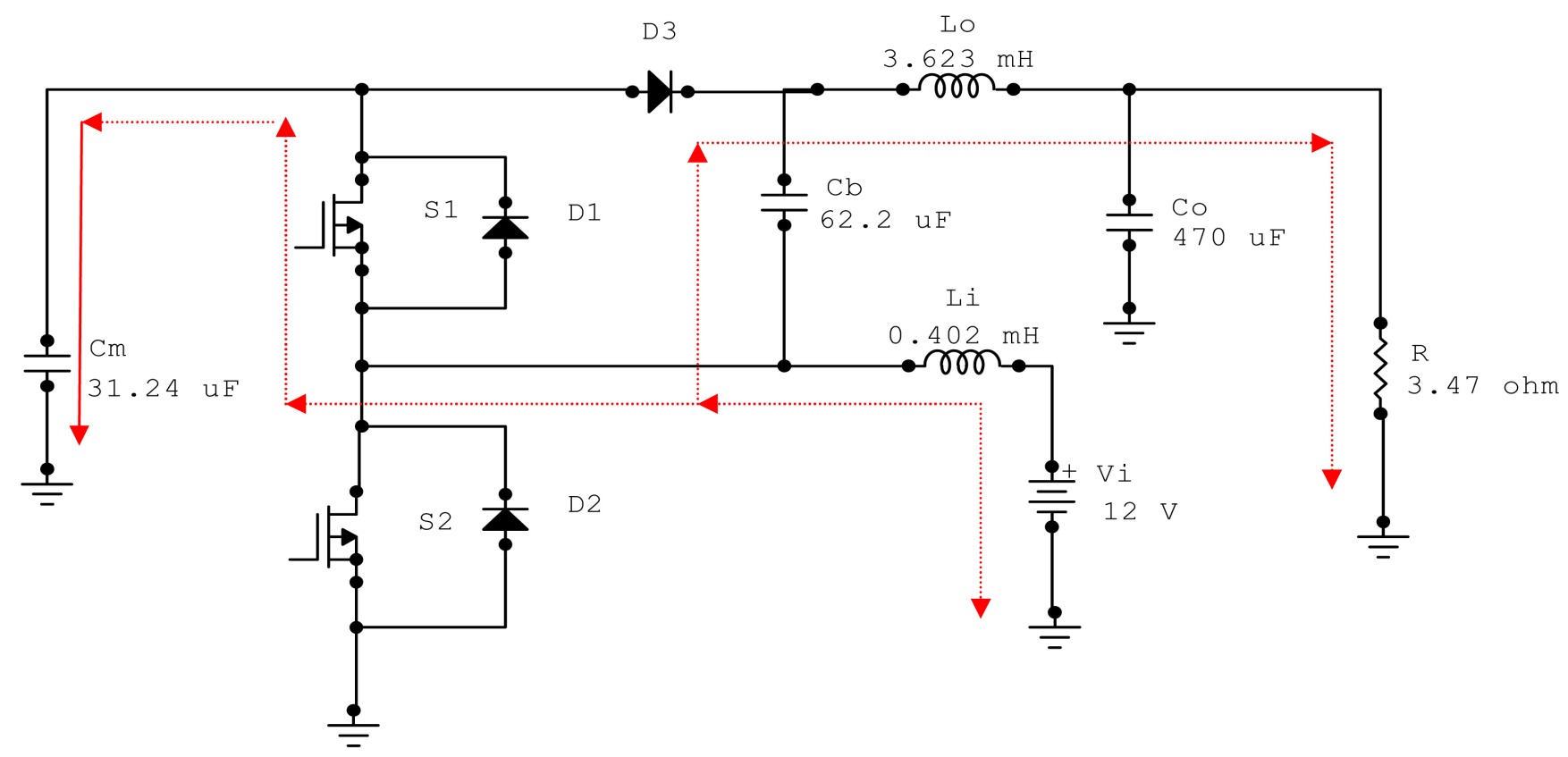

Figure 4. Power flow of mode 2 operation.

and hence $D_{b}$ is reverse biased and turned off. During this mode, $C_{m}$ is charged whereas $C_{b}$ is discharged. Therefore, the voltage across $L_{i}$ is $V_{C m}$ subtracted from $V_{i}$, thereby causing $L_{i}$ to be demagnetized, whereas the voltage across $L_{0}$ is $V_{0}$ subtracted from sum of $V_{C m}$ and $V_{C b}$, thereby causing $L_{0}$ to be magnetized. Also, the current flowing through Co is equal to $i_{L o}$ minus the current flowing through $i_{L o}$. And hence, the corresponding differential equations are given by (5) to (8). 


$$
\begin{gathered}
L_{i} \frac{\partial i_{L i}}{\partial t}=V_{i}-V_{C m} \\
L_{o} \frac{\partial i_{L o}}{\partial t}=2 V_{C m}-V_{0} \\
C_{m} \frac{\partial V_{C m}}{\partial t}=i_{L i}-i_{L o} \\
C_{o} \frac{\partial V_{o}}{\partial t}=i_{L o}-\frac{V_{o}}{R_{L}}
\end{gathered}
$$

The average equations which are obtained from Equation (1) to Equation (8), are given by (9) to (13).

$$
\begin{gathered}
L_{i} \frac{\partial i L_{i}}{\partial t}=\left(V_{i}\right)-(1-d)\left(V_{c m}\right) \\
C_{o} \frac{\partial V_{o}}{\partial t}=\left(i L_{o}\right)-\left(\frac{V_{o}}{R_{L}}\right) \\
\frac{\partial i_{L o}}{\partial t}=(2-d)\left(V_{C m}\right)-\left(V_{o}\right) \\
C_{m} \frac{\partial\left(V_{C m}\right)}{\partial t}=\left(-i_{L o}\right)+(1-d)\left(i_{L i}\right)-d\left(i_{C b}\right) \\
\frac{C_{b}}{C_{m}}=\frac{\left(\left(\frac{1-d}{d}\right)\left(i_{L o}\right)\right)}{\left(-\left(\frac{1-d}{d}\right)\left(i_{L o}\right)+i_{L i}(1-d)-\left(i_{L o}\right)\right)}
\end{gathered}
$$

where,

$$
\begin{aligned}
& \frac{\partial i L_{i}}{\partial t}=2 \% \text { of } i_{L i} \\
& \frac{\partial i_{L o}}{\partial t}=2 \% \text { of } i_{L o} \\
& \frac{\partial\left(V_{C m}\right)}{\partial t}=2 \% \text { of } V_{C m} \\
& \frac{\partial V_{o}}{\partial t}=2 \% \text { of } V_{o}
\end{aligned}
$$

According to the small-ripple approximation and the voltage-second balance, the voltage ratio can be obtained to be

$$
\frac{V_{0}}{V_{i}}=\frac{2-d}{1-d}
$$

where,

$d=$ Duty cycle.

$V_{o}=$ Output voltage in Volts.

$V_{i}=$ input voltage in Volts.

From Equations (9) to (14), we can obtain the specification values for KY boost converter. Here $2 \%$ of ripple will be taken for finding the specification values for KY boost 
converter.

\subsection{KY Boost Converter Specifications}

Table 1 gives a detailed specification adopted for analyzing the performance of KY boost converter.

\subsection{KY Boost Converter Simulink Modeling}

The KY boost converter realized in Simulink model is represented by Figure 5, in which switches are represented by $S_{1}$ and $S_{2}$ with interrelated body diodes $D_{1}$ and

Table 1. Specifications adopted for KY boost converter.

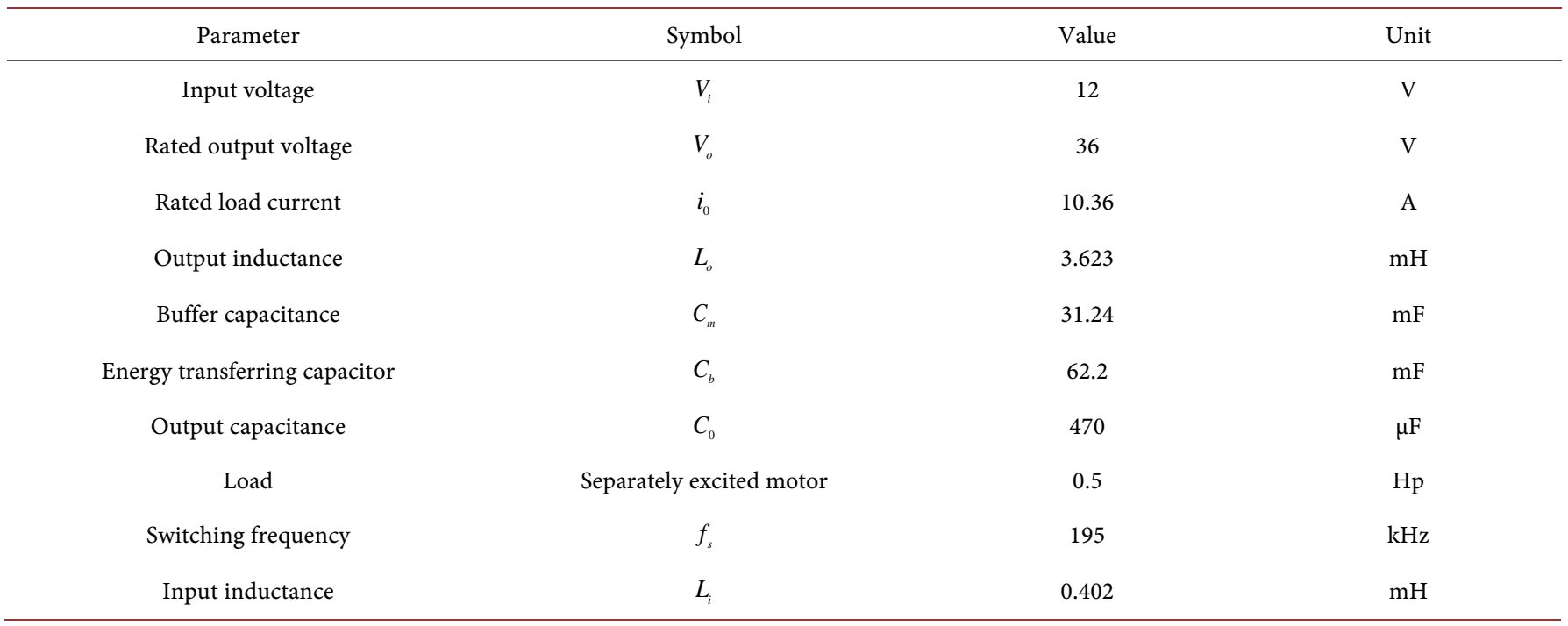

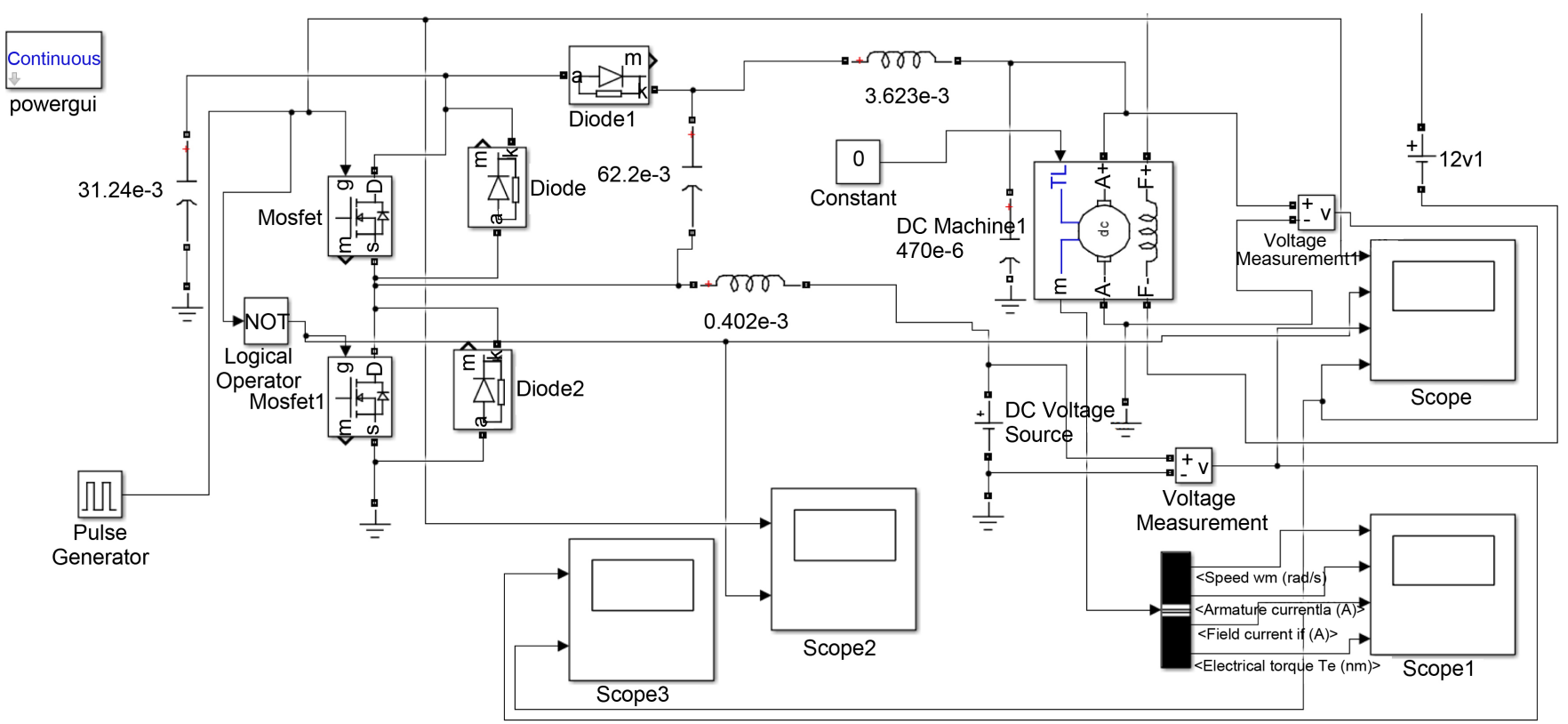

Figure 5. KY boost converter Simulink model. 


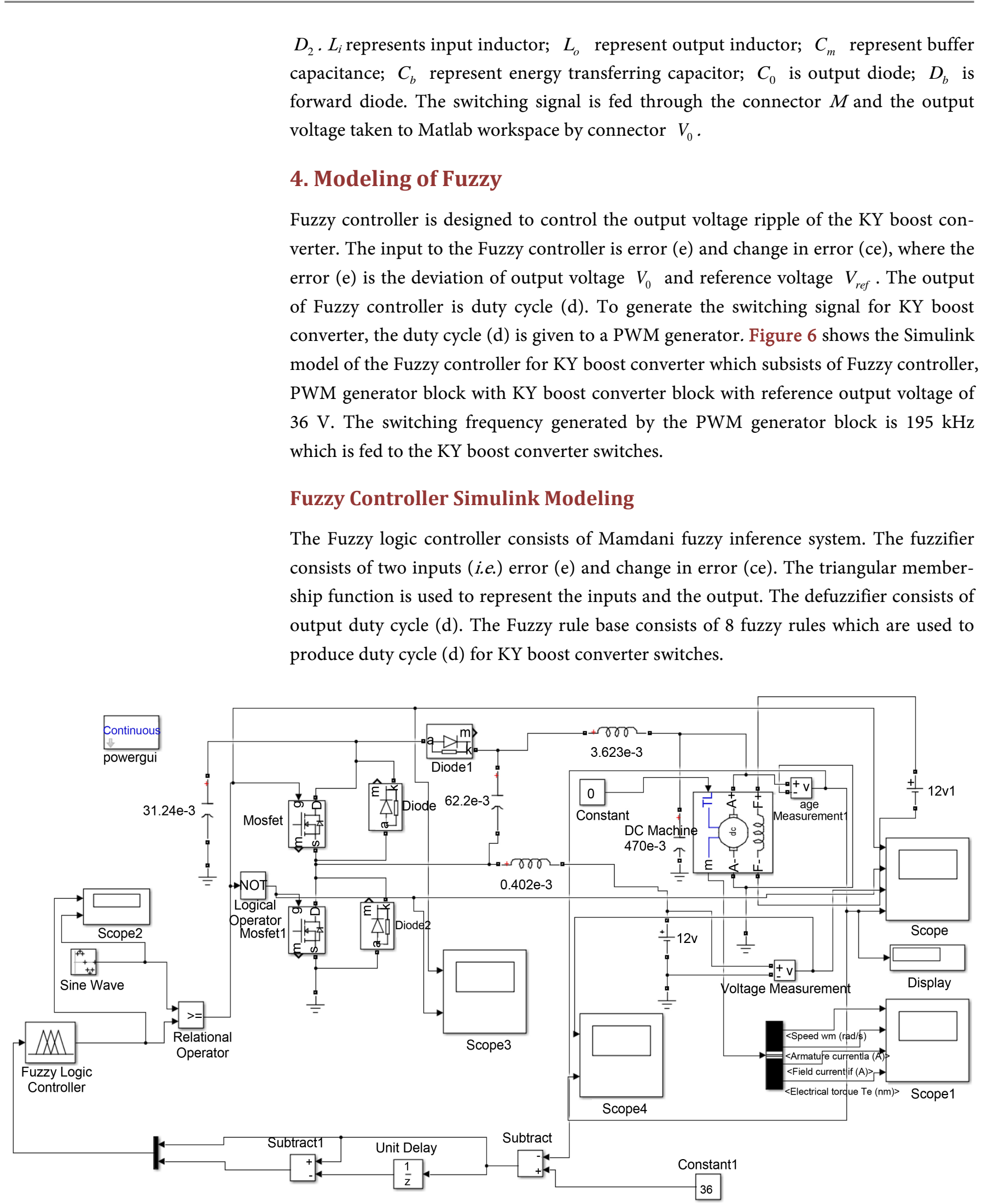

Figure 6. KY fuzzy controller Simulink model. 


\section{Modeling of PSO}

Particle Swarm Optimization (PSO) comes from the research on the bird and fish flock movement behavior which is used to find the global minimum of the proposed objective function. In this method a swarm of particles describe a candidate solution move in the search space. Each particle position represents the objective function which is depending on the variables defined by the optimization problem. It is simple and easy to implement. It does not require any specific information about the converter model as well as the system parameters. And the calculation is very simple but the step for the calculation is high. Figure 7 shows the steps to be adapted for PSO.

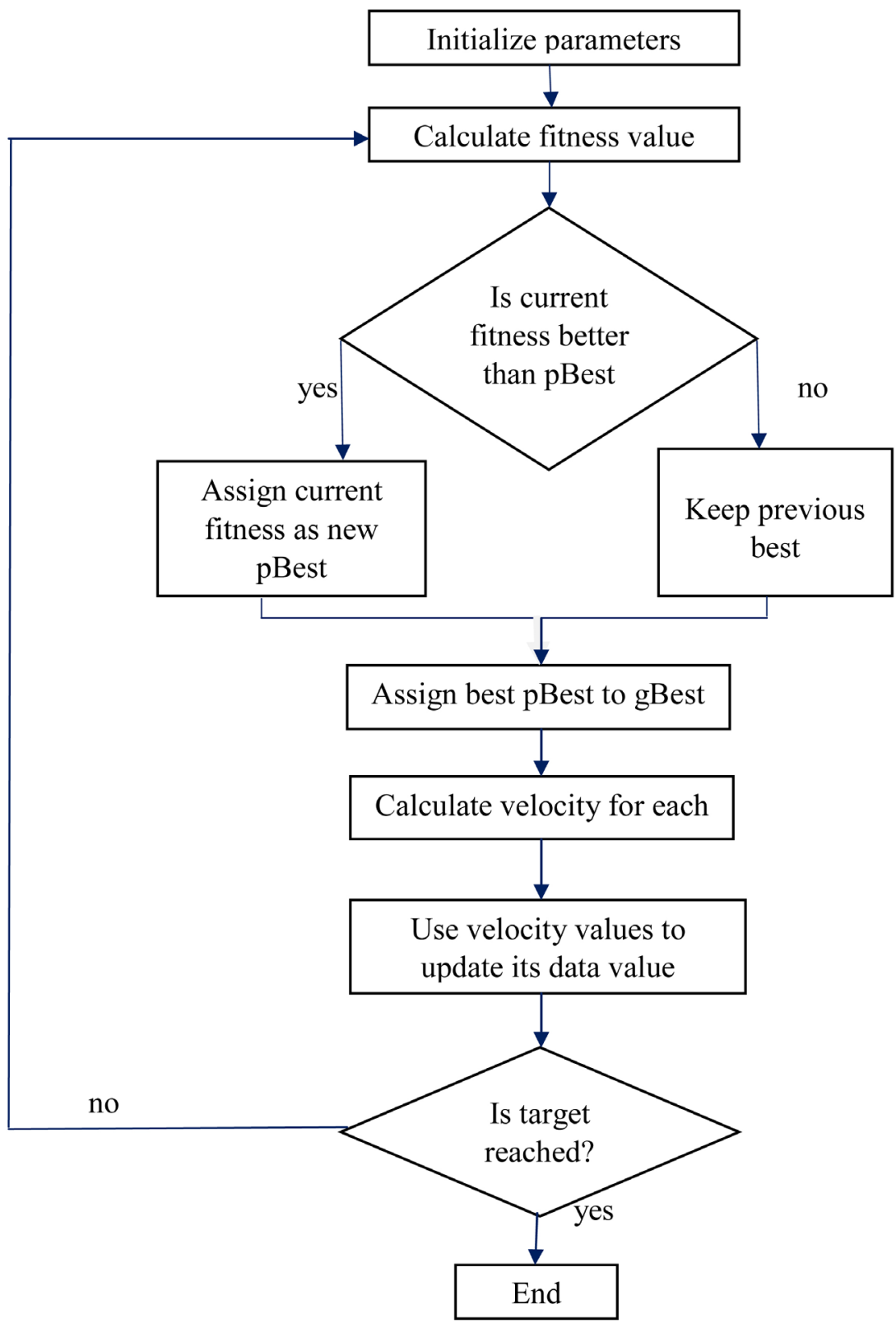

Figure 7. Flow chart for PSO. 


\section{PSO Controller Simulink Modeling}

The aim of the present work is to find out the optimized vector of the switching angles, for which the ripple components are limited to acceptable low level or even to be eliminated. On the other side, the obtained average value has to be equal or closer to the reference or desired output voltage. To fulfill these requirements an objective function which has to be minimized is proposed as follows:

$$
f(d)=e
$$

where,

$$
\begin{gathered}
e=V_{\text {ref }}-V_{a v g} \\
V_{\text {ref }}=36 \\
V_{\text {ripple }}=0.02
\end{gathered}
$$

This function contains two terms, the error between the desired average voltage and the obtained output average voltage and the output voltage ripple which is to be eliminated. For reducing the output voltage ripple the output voltage should satisfy the following Constrain.

$$
d=0 \text { to } 1
$$

\section{Simulation Results and Discussion}

The simulated results of the KY boost converter with input voltage $12 \mathrm{~V}$ and the rated output voltage of $36 \mathrm{~V}$ for a load current of $10.36 \mathrm{~A}$ is simulated with Matlab/Simulink R2013a as shown in Figure 8. Figure 9 shows the switching pulse of KY boost converter for S1 and S2. The inverted switching pulse of S1 is given to S2.

Figure 10 shows the output voltage for $12 \mathrm{~V}$ input voltage in open loop condition of $\mathrm{KY}$ boost converter. It clearly shows that the output voltage ripple for an output voltage of $32.18 \mathrm{~V}$ in open loop condition is about $1.18 \mathrm{~V}$.

$$
\text { OUTPUT VOLTAGE RIPPLE }=V_{\max }-V_{\min }=32.18 \mathrm{~V}-31 \mathrm{~V}=1.18 \mathrm{~V}
$$

Figure 11 shows the switching pulse of closed loop KY boost converter using fuzzy logic controller for S1 and S2. The inverted pulse of S1 is given to S2. From this it is observed that the duty cycle will be varied based on error and change in error of output voltage.

Figure 12 shows the output voltage for $12 \mathrm{~V}$ input voltage in closed loop condition of KY boost converter using FUZZY controller. It clearly shows that the output voltage ripple for an output voltage of $36 \mathrm{~V}$ is about $0.54 \mathrm{~V}$.

Figure 13 shows the switching pulse of KY boost converter using PSO algorithm based controller for S1 and S2. The inverted pulse of S1 is given to S2. From this it is observed that the duty cycle will be varied based on the updating of position and velocity.

Figure 14 shows the output voltage for $12 \mathrm{~V}$ input voltage in closed loop condition of KY boost converter using PSO based controller. It clearly shows that the output 


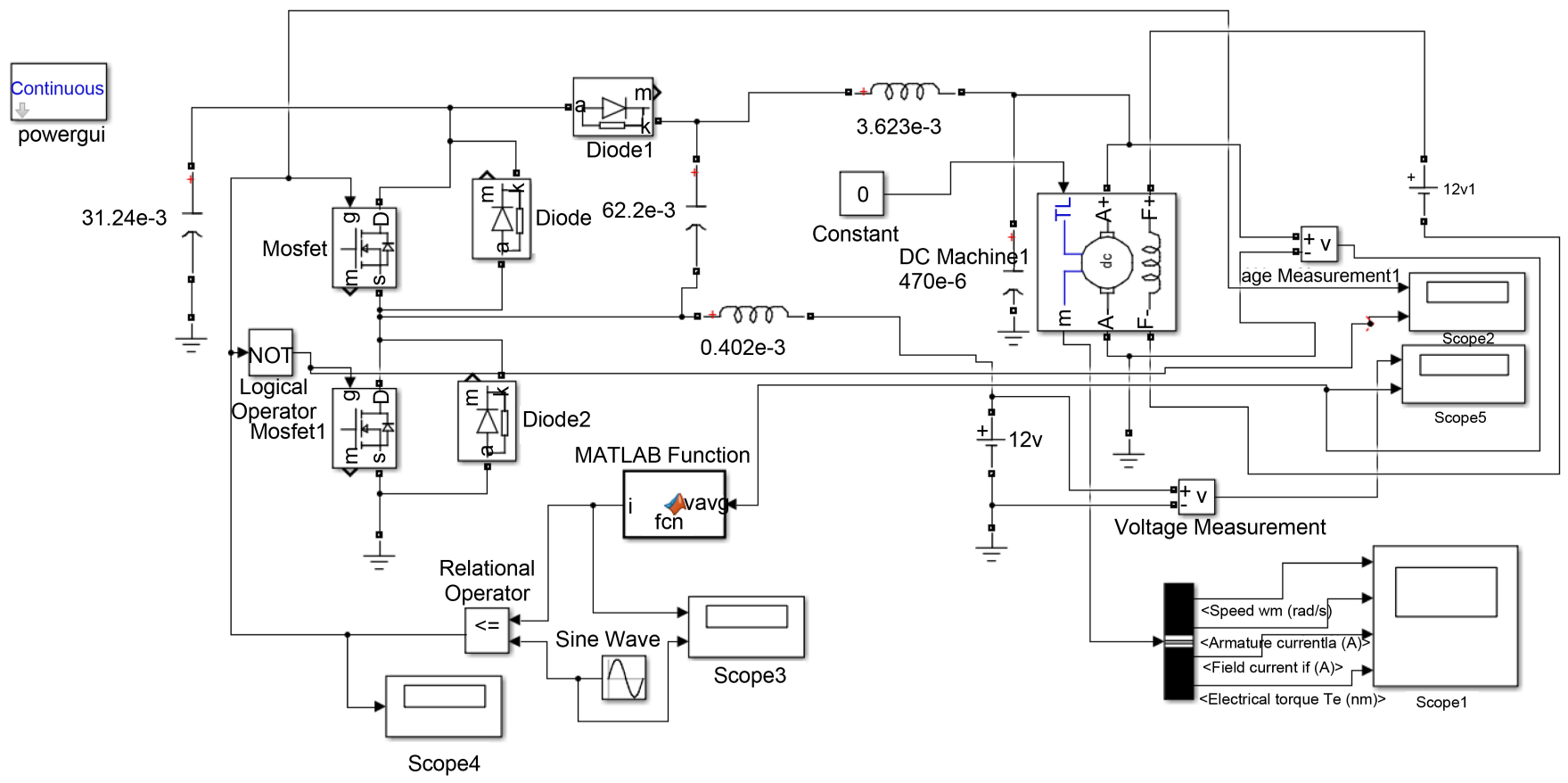

Figure 8. KY PSO controller Simulink model.
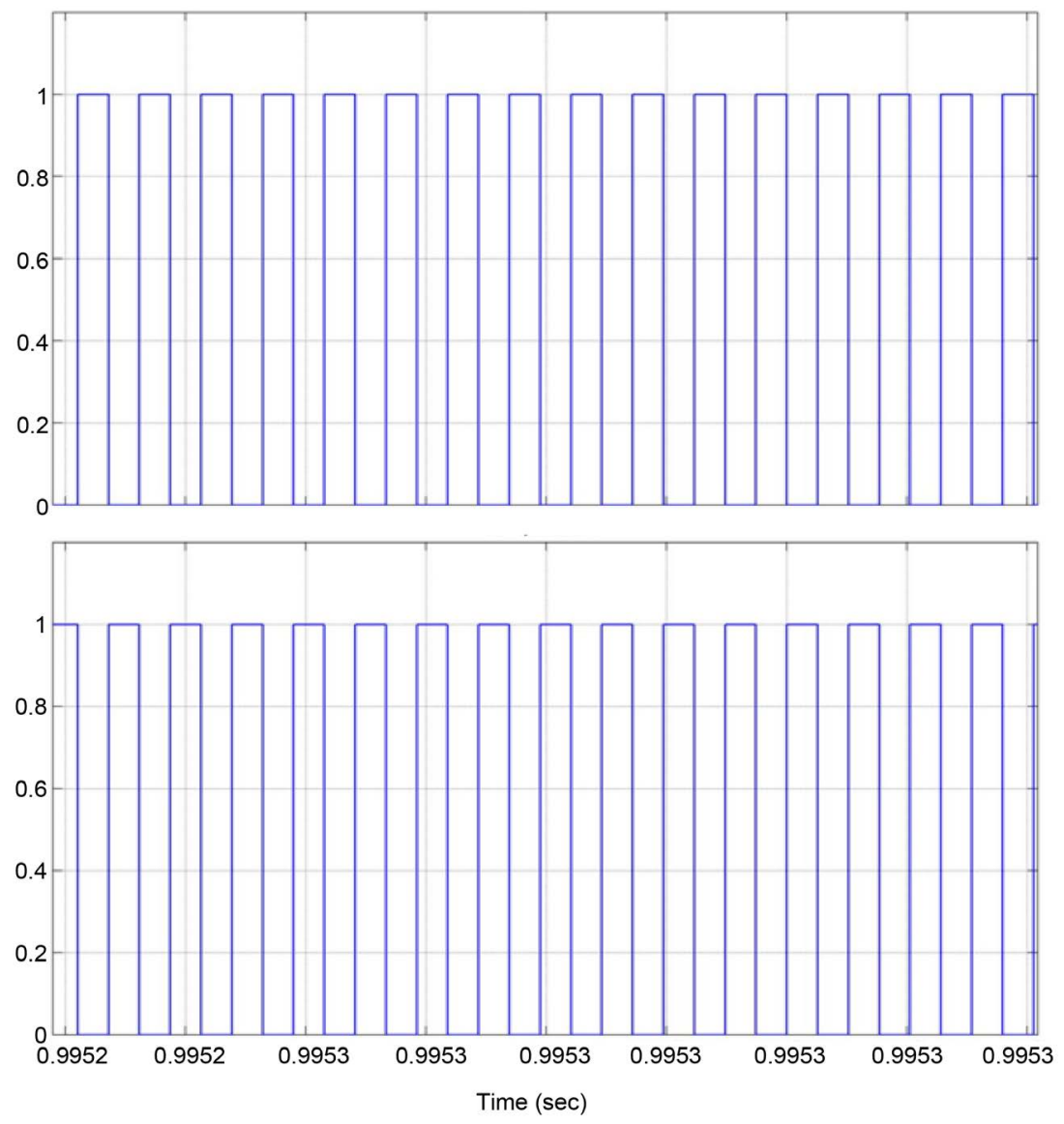

Figure 9. Switching pulse for KY boost converter in open loop condition. 
voltage ripple for an output voltage of $36 \mathrm{~V}$ is about $0.29 \mathrm{~V}$.

OUTPUT VOLTAGE RIPPLE $=V_{\max }-V_{\min }=36 \mathrm{~V}-35.71 \mathrm{~V}=0.29 \mathrm{~V}$

\section{Conclusion}

The problem of the KY Boost converter output voltage ripple is presented in this paper. The Particle Swarm Optimization PSO algorithm is used to solve this problem using an objective function. This objective function contains a defined number of switching angles pattern depending on the degree of ripple reduction. The resulting output values of the proposed PSO Controller are compared with the existing FUZZY logic controller

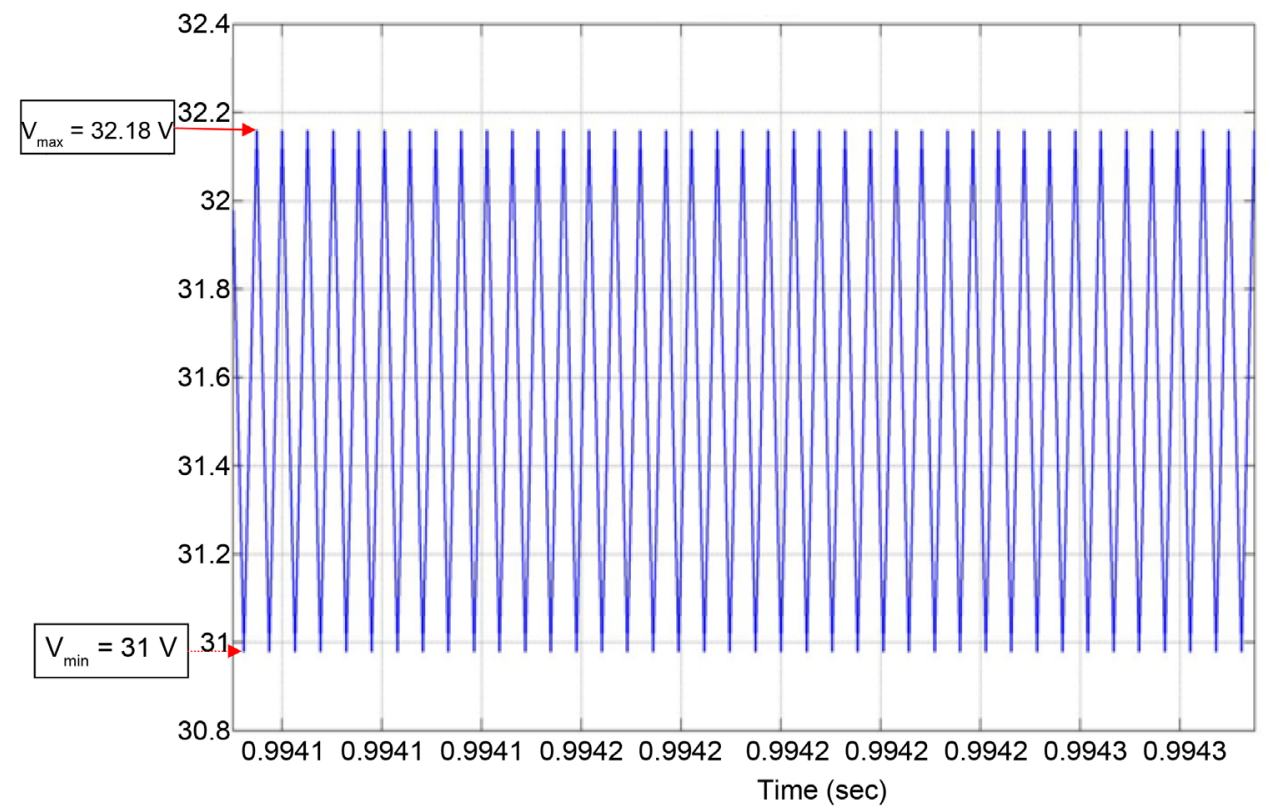

Figure 10. Output voltage waveform of open loop KY boost converter.

SWITCHING PULSE FOR S1 AND S2

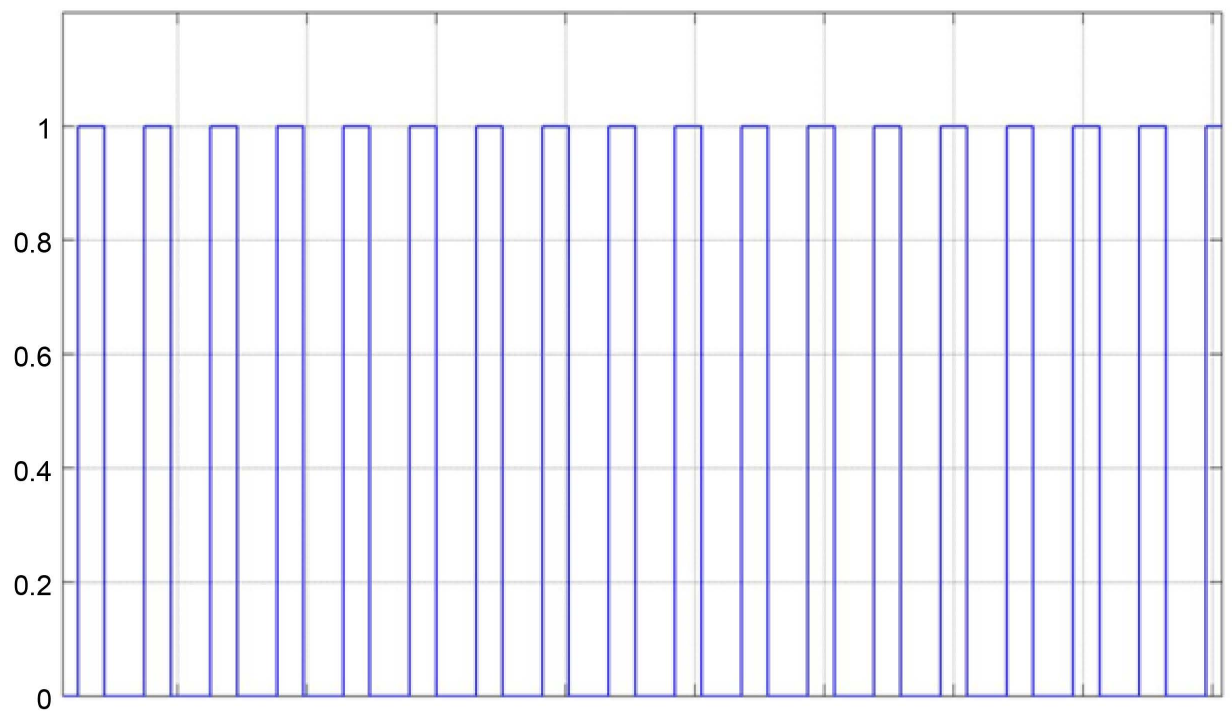




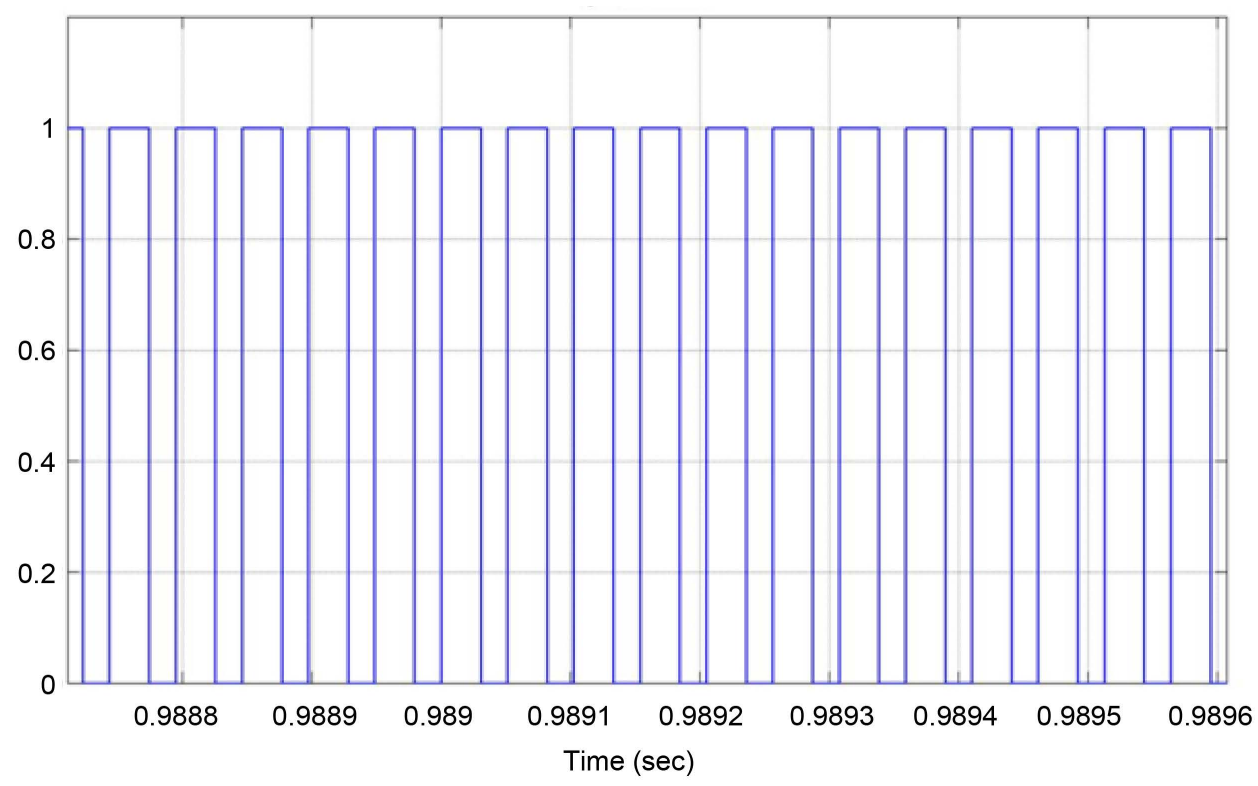

Figure 11. Switching pulse for KY boost converter in closed loop condition using FUZZY logic controller.

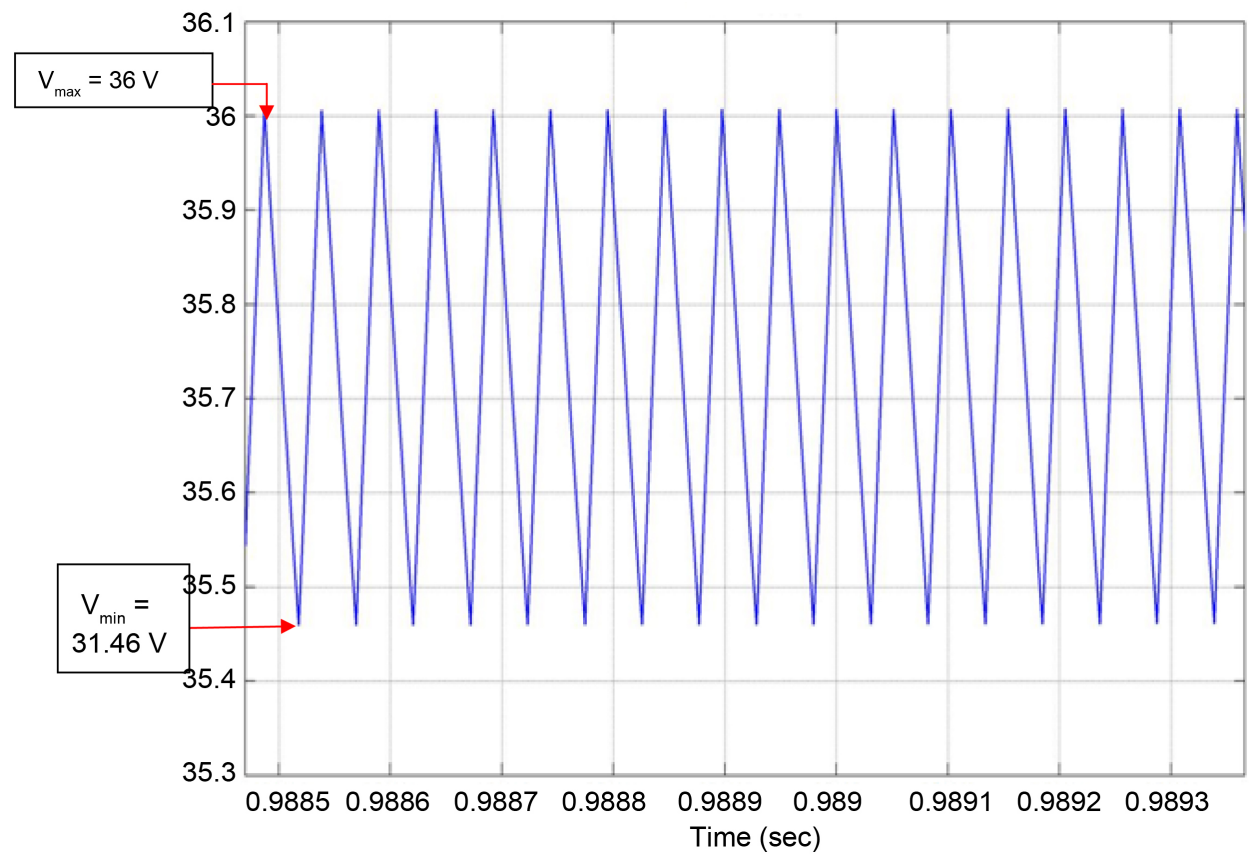

Figure 12. Output voltage waveform of closed loop KY boost converter using FUZZY logic controller.

output and the open loop system. The minimization of output voltage ripple from 1.18 $\mathrm{V}$ in open loop system to $0.54 \mathrm{~V}$ in FUZZY based converter and further minimization to $0.29 \mathrm{~V}$ in PSO based converter is proved by the simulation results comparison shown in Table 2. And the future work could be continued by using various renewable sources as an input voltage source instead of constant voltage source like battery and can be 
SWITCHING PULSE FOR S1 AND S2
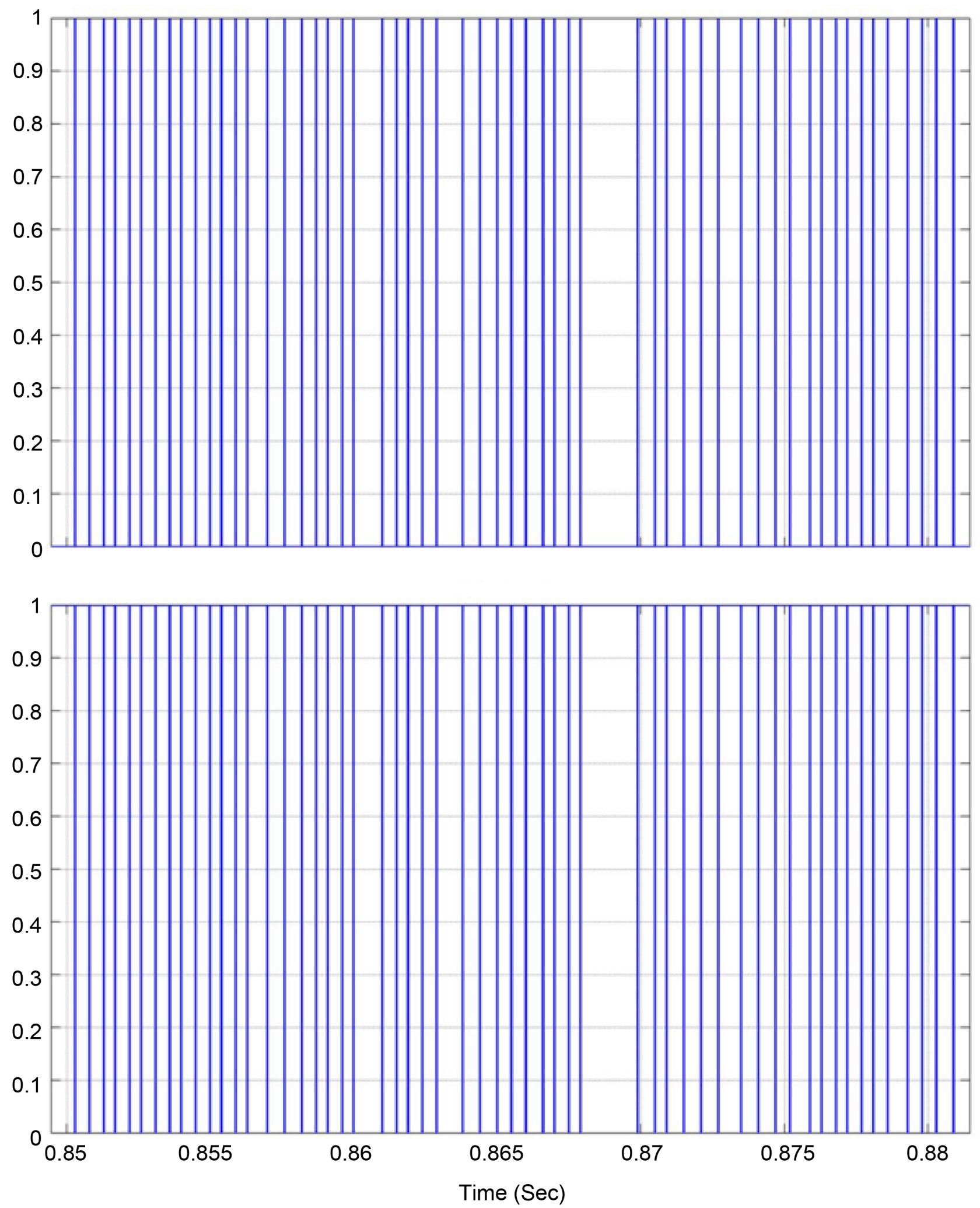

Figure 13. Switching pulse for KY boost converter in closed loop condition using PSO based controller. 


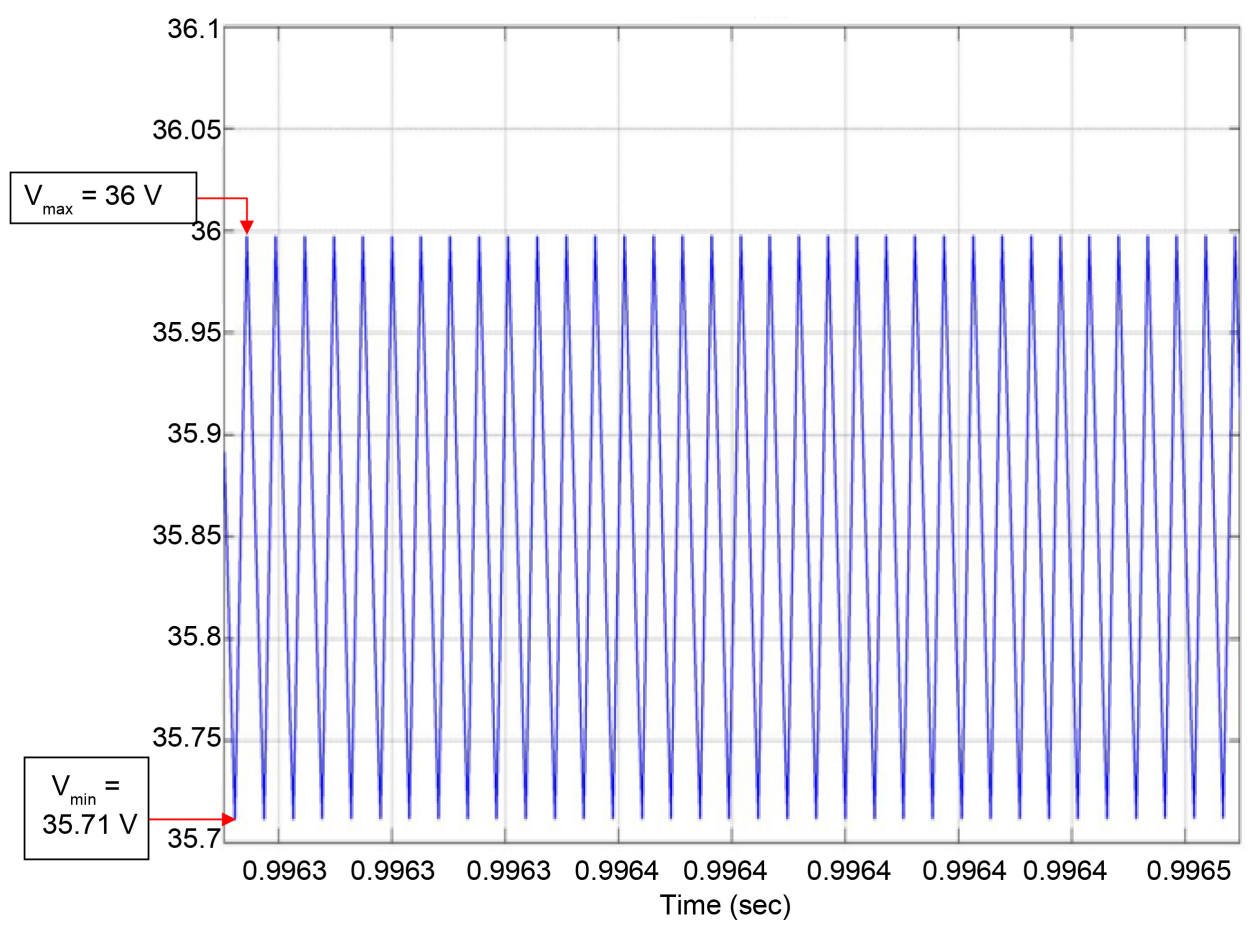

Figure 14. Output voltage waveform of closed loop KY boost converter using PSO based controller.

Table 2. Comparison of existing and proposed technique output.

\begin{tabular}{cccc}
\hline Parameter & $\begin{array}{c}\text { Existing open loop } \\
\text { system }\end{array}$ & $\begin{array}{c}\text { Existing FUZZY logic } \\
\text { controller }\end{array}$ & $\begin{array}{c}\text { Proposed PSO based } \\
\text { controller }\end{array}$ \\
\hline Output voltage ripple & $1.18 \mathrm{~V}$ & $0.54 \mathrm{~V}$ & $0.29 \mathrm{~V}$ \\
\hline
\end{tabular}

compared in hybrid condition.

\section{References}

[1] Giral, R., Arango E., Calvente, J. and Martinez-Salamero, L. (2002) Inherent DCM Operation of the Asymmetrical Interleaved Dual Buck-Boost. Proceedings IEEE IECON Conference, $1,129-134$.

[2] Luo, F.L. and Ye, H. (2003) Negative Output Super-Lift Converters. IEEE Transactions on Power Electronics, 18, 1113-1121. http://dx.doi.org/10.1109/TPEL.2003.816185

[3] Luo, F.L. and Ye, H. (2003) Positive Output Super-Lift Converters. IEEE Transactions on Power Electronics, 18, 105-113. http://dx.doi.org/10.1109/TPEL.2002.807198

[4] Luo, F.L. (1999) Positive Output Luo Converters Voltage Lift Technique. IEE Proceedings Electric Power Applications, 146, 415-432. http://dx.doi.org/10.1049/ip-epa:19990291

[5] Shin, H.B., Park, J.G., Chung, S.K., Lee, H.W. and Lipo, T.A. (2005) Generalized SteadyState Analysis of Multiphase Interleaved Boost Converter with Coupled Inductors. IEE Proceedings Electric Power Applications, 152, 584-594. http://dx.doi.org/10.1049/ip-epa:20045052

[6] Savu, C., Radoi, A. and Florescu, A. (2010) Sliding Mode PWM Control for a Buck Con- 
verter under DCM/CCM Boundary. International Review of Electrical Engineering, 5, 1963-1971.

[7] Hong, Y.U., Jung, S.H., Woo, Y.J., Choi, B.K. and Cho, G.H. (2005) Single Chip QuasiPWM DC-DC Converter with Fast Transient Response Comprising Loop-Bandwidth Control. IEEE Letters, 41, 501-503. http://dx.doi.org/10.1049/el:20058183

[8] Hwu, K.I. and Yau, Y.T. (2010) A KY Boost Converter. IEEE Transactions on Power Electronics, 25, 2699-2703. http://dx.doi.org/10.1109/TPEL.2010.2051235

[9] Hwu, K.I. and Jiang, W.Z. (2014) Voltage Gain Enhancement for a Step-Up Converter Constructed by KY and Buck-Boost Converters. IEEE Transaction on Industrial Electronics, 61, 1758-1768. http://dx.doi.org/10.1109/TIE.2013.2263779

[10] Hwu, K.I. and Yau, Y.T. (2009) KY Boost Converter and Its Derivatives. IEEE Transactions on Power Electronics, 24, 128-137. http://dx.doi.org/10.1109/TPEL.2008.2009178

[11] Karthikumar, S., Mahendran, N. and Sriraman, S. (2012) Design of Fuzzy Logic Controller for Output Voltage Ripple (OVR) Reduction of KY Boost Converter. IEEE Proceedings Emerging Trends in Electrical Engineering and Energy Management, 181-185. http://ieeexplore.ieee.org/document/6494468/

\section{Submit or recommend next manuscript to SCIRP and we will provide best service for you:}

Accepting pre-submission inquiries through Email, Facebook, LinkedIn, Twitter, etc. A wide selection of journals (inclusive of 9 subjects, more than 200 journals)

Providing 24-hour high-quality service

User-friendly online submission system

Fair and swift peer-review system

Efficient typesetting and proofreading procedure

Display of the result of downloads and visits, as well as the number of cited articles Maximum dissemination of your research work

Submit your manuscript at: http://papersubmission.scirp.org/

Or contact cs@scirp.org 